\title{
The Role of Genetics Among Stroke Risk Factors: Discussion of Two Rare Genetic Syndromes Associated with Stroke and Literature Review
}

\author{
İnme Risk Faktörleri Arasında Genetiğin Yeri; Nadir Görülen İki Sendromun İnmeyle \\ Birlikteliğinin Tartışılması ve Literatür Taraması
}

Eda Kılıç Çoban, Nilüfer Kale İçen, Mesude Özerden Acar, Melek Çolak Atmaca, Aysun Soysal Bakırköy Research and Training Hospital for Psychiatry, Neurology and Neurosurgery, Clinic of $3^{\text {rd }}$ Neurology, İstanbul, Türkiye

\section{Summary}

Stroke is defined as a focal or global neurologic impairment of sudden onset that lasts more than 24 hours or leads to death. The non-modifiable risk factors of stroke include age, race, and sex, and modifiable risk factors include smoking, hypertension, diabetes, and obesity. Previous studies have shown that these risk factors may be responsible for approximately $50 \%$ of patients who present with stroke. However, no risk factors were identified in the remaining half, and genetics may have been responsible for this group. In this manuscript, we present 2 patients with rare genetic syndromes, Marfan's syndrome and Robinow syndrome, who were referred to our clinic with stroke and had no other identifiable risk factors, and highlight the role of genetic syndromes in stroke etiology.

Keywords: Marfan, Robinow, syndrome, stroke, genetics

$\ddot{\mathbf{O z}}$

İnme akut gelişen, serebral işlevlerin fokal, kimi zaman global kaybına bağlı klinik semptom ve/veya bulgulardır. İnmede değiştirilemeyen risk faktörleri yaş, ırk, cinsiyet olarak sıralanırken, kazanılmış risk faktörleri arasında sigara kullanımı, hipertansiyon, diyabet, obezite ön sıralarda yer almaktadır. Yapılan çalışmalarda bu risk faktörlerinin yaklaşık \%50'sinin etiyolojide inme nedeni olduğu, geri kalan nedenler arasında genetik nedenlerin de önemli rol aldığı vurgulanmıştır. Bu yazımızda nadir görülen genetik sendromlardan Marfan sendromu ve Robinow sendromu tanısı ile takip edilmekte olan ve inme için başka bir risk faktörü saptanmamış iki olgumuzu sunarak, genetik sendromların inme etiyolojisindeki rolüne dikkat çekmeyi amaçladık.

Anahtar kelimeler: Marfan, Robinow, sendrom, inme, genetik

\section{Introduction}

Stroke encompasses rapidly developing clinical symptoms and/or signs of focal or rarely global loss of cerebral function that last longer than 24 hours or lead to death, with no apparent non-vascular cause (1). The non-modifiable risk factors of stroke have been listed as age, race, and sex, and the modifiable risk factors include smoking, hypertension diabetes, and obesity. The prospective study of Sacco et al. (2) (1989) in 1805 patients with stroke showed that stroke risk factors were identified in $50 \%$ of the patients, and suggested genetic factors were responsible for the remaining cases. The role of genetic factors is controversial in stroke because of its heterogeneous etiopathogenesis; family studies, twin studies and genetic investigations have provided different results (3). Genetic disorders that cause stroke have been classified as single gene or polygenic disorders. Although there are a great number of studies in the literature on genes that create a potential risk for stroke, the most prominent advancements have been achieved in the area of single gene disorders, including cerebral autosomal dominant arteriopathy with subcortical infarcts and leucoencephalopathy (CADASIL); cerebral autosomal recessive arteriopathy with subcortical infarcts and leucoencephalopathy (CARASIL); Moyamoya disease; Fabry disease; sickle cell anemia; homocystinuria, mitochondrial myopathy encephalopathy, lactic acidosis, and stroke (MELAS), Marfan's syndrome; and EhlersDanlos syndrome type IV $(2,4)$. Family history and anamnesis

Address for Correspondence/Yazışma Adresi: Eda Kılıç Çoban MD, Bakırköy Research and Training Hospital for Psychiatry, Neurology and Neurosurgery, Clinic of $3^{\text {rd }}$ Neurology, İstanbul, Türkiye

Phone: +90 21240915 15-1840 E-mail: eda_coban@yahoo.com

Received/Geliş Tarihi: 05.03.2014 Accepted/Kabul Tarihi: 21.10.2014 
alert the physician in some of these disorders to genetic origin, and phenotypic features prove diagnostic in others.

Our objective was to highlight the role of genetic syndromes in stroke etiology by presenting two patients with Marfan's syndrome and Robinow syndrome who had no other identifiable risk factors for stroke.

\section{Case Reports}

\section{Case 1}

A man aged 45 years presented to our emergency neurology clinic with weakness in his right arm, and inability to speak and comprehend. His medical history involved hypertension; an operation for an aortic aneurysm, a dissection extending from abdominal aorta to iliac artery; and a coronary by-pass operation. His routine medications included metoprolol $50 \mathrm{mg} /$ day, ramipril $5 \mathrm{mg} /$ day, and acetylsalicylic acid $100 \mathrm{mg} /$ day. He had marfanoid appearance on physical examination (Figure 1a, b, c). Blood pressure was measured as $140 / 90 \mathrm{mmHg}$. The patient was dysarthric, and had mild paresis in the right arm and leg (Medical Research Council (MRC) 5/5) on neurologic examination. Cranial magnetic resonance imaging (MRI) revealed acute infarction in the left middle cerebral artery (MCA) territory (Figure 2a, b, c). Transthoracic echocardiography (ECHO) that was performed to elucidate etiology showed moderate aortic insufficiency. Bilateral carotid and vertebral artery Doppler ultrasonography (USG) proved insignificant; however, cranial MR angiography delineated

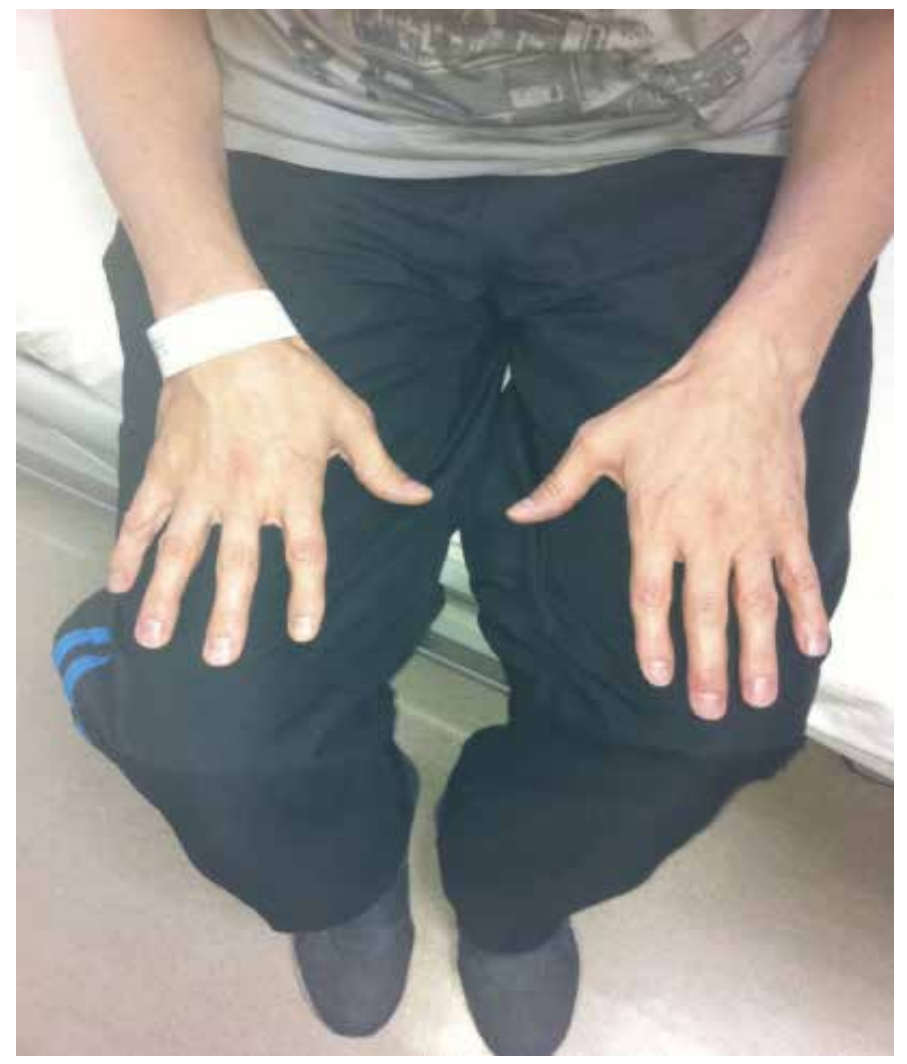

Figure 1a. Long extremities due to the linear prolongation of long bones in Marfan's syndrome contour irregularity in vertebral artery, and a pseudoaneurysm in the V2 segment of the right vertebral artery. Young-stroke workup and vasculitic markers (homocysteine, lupus erythematosus cell, lupus anticoagulant, antithrombin III, fibrinogen, protein C activity, protein $\mathrm{S}$ activity, anticardiolipin $\operatorname{IgM}$, anticardiolipin IgG, antinuclear antibody, anti-neutrophil cytoplasmic antibody, p-ANCA, ENA profile, complement C3, complement C4, prothrombin gen II mutation, and factor V Leiden mutation) were within normal ranges. The eye examination was also normal. The department of cardiology recommended against the performance of transesophageal ECHO (TEE) because of the risk posed by dissection. No additional oral anti-coagulant drugs were initiated. The patient was discharged with clopidogrel $75 \mathrm{mg} /$ day therapy and was to be followed up at neurology outpatient and cardiology clinics.

\section{Case 2}

A man aged 24 years presented to our emergency clinic with symptoms of weakness in his right arm and leg. The patient's family medical history revealed that both he and his brother had been diagnosed as having Robinow syndrome and was being followed up by the division of genetics of the department of pediatrics. Physical examination revealed fetal facies, hypertelorism, upturned nose, short stature, and short forearm and small hands (Figure 3a, b). Right hemiparestesia (MRC -5/5) was determined in the neurologic examination, and cranial MRI

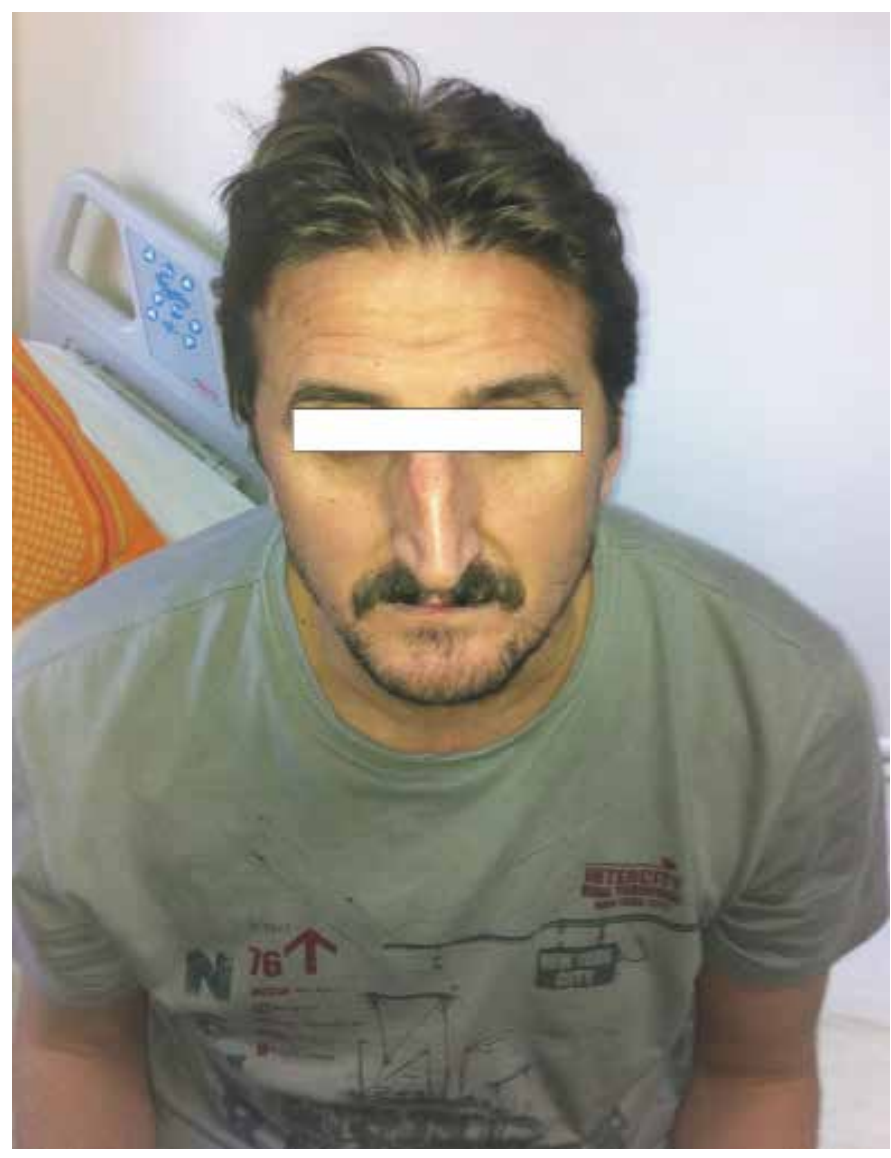

Figure 1b. Long and slim appearing face in Marfan's syndrome 
showed acute infarction in the left MCA territory (Figure 4a, b, c). Transthoracic ECHO examination was normal. Doppler USG examination of the cervical arteries proved insignificant other than minimal atherosclerotic changes. MR-angiographies were also normal. The results of the young stroke workup and vasculitic markers, which were performed for differential diagnosis, were within normal ranges. The main rhythm was sinusoidal in Holter rhythm monitorization. TEE aimed at further investigation was interpreted as normal. Anti-aggregative therapy (acetylsalicylic acid $300 \mathrm{mg}$ /day) was started and the patient was discharged upon improvement of neurologic symptoms to be followed up at the neurology outpatient's clinic.

\section{Discussion}

Marfan's syndrome is an autosomal dominant connective tissue disorder that results from a mutation in the fibrillin gene coded by chromosome 15, and is characterized by involvement of skeletal, ocular, and cardiovascular systems (5). The disease pathophysiology embodies injury to elastic fibers due to a fibrillin defect in medium and large arteries, which results in aneurysm formation and arterial dissection. These vascular pathologies might lead to cerebral and/ or spinal ischemia or hemorrhage (6). However, neurovascular complications are rare in patients with Marfan's syndrome. The results of an 8-year surveillance study on Marfan's syndrome by Wityk et al. (6) in 2002 identified neurovascular events such as

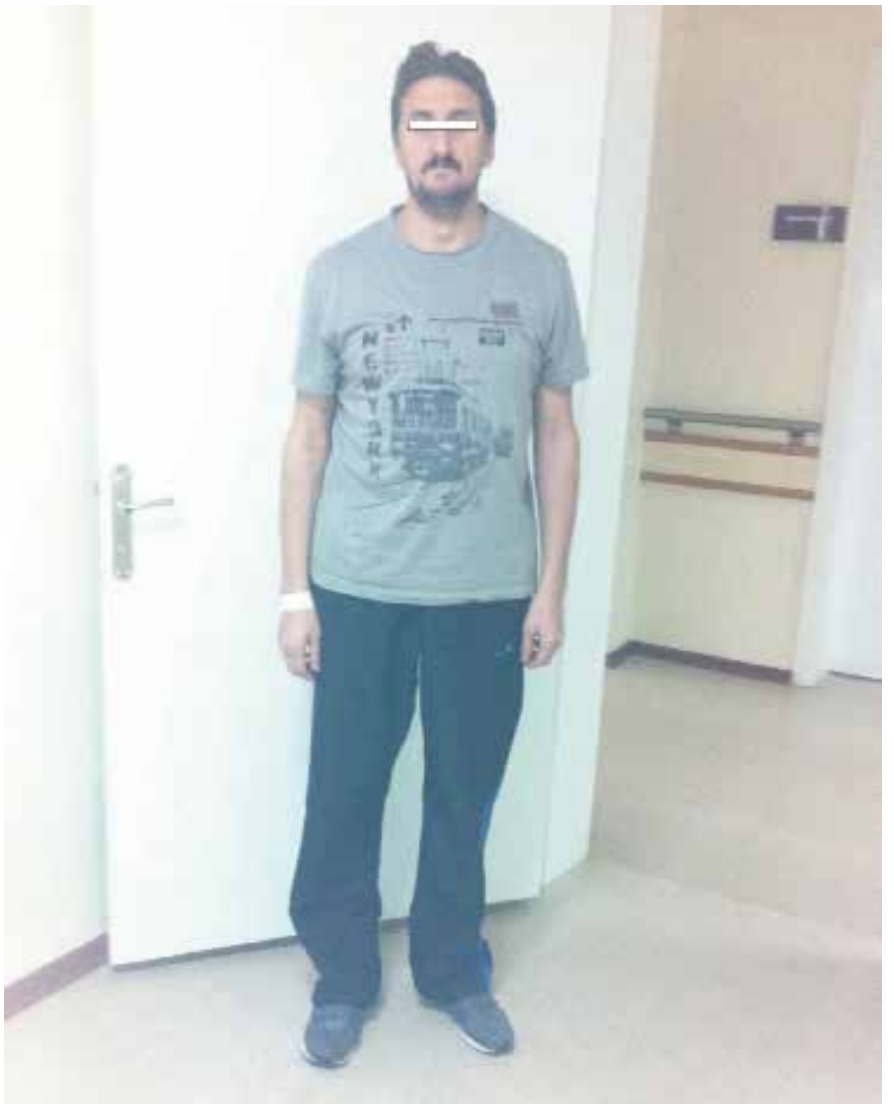

Figure 1c. Abnormal arm span, increased arm span/stature ratio in Marfan's syndrome transient ischemic attacks (65\%), cerebral infarction (10\%), spinal cord infarction (10\%), subdural hemorrhage (10\%), and spinal subarachnoid hemorrhage ( $5 \%$ ), in only $3.5 \%$ of the patients. A cardioembolic origin was demonstrated in 12 out of 13 patients

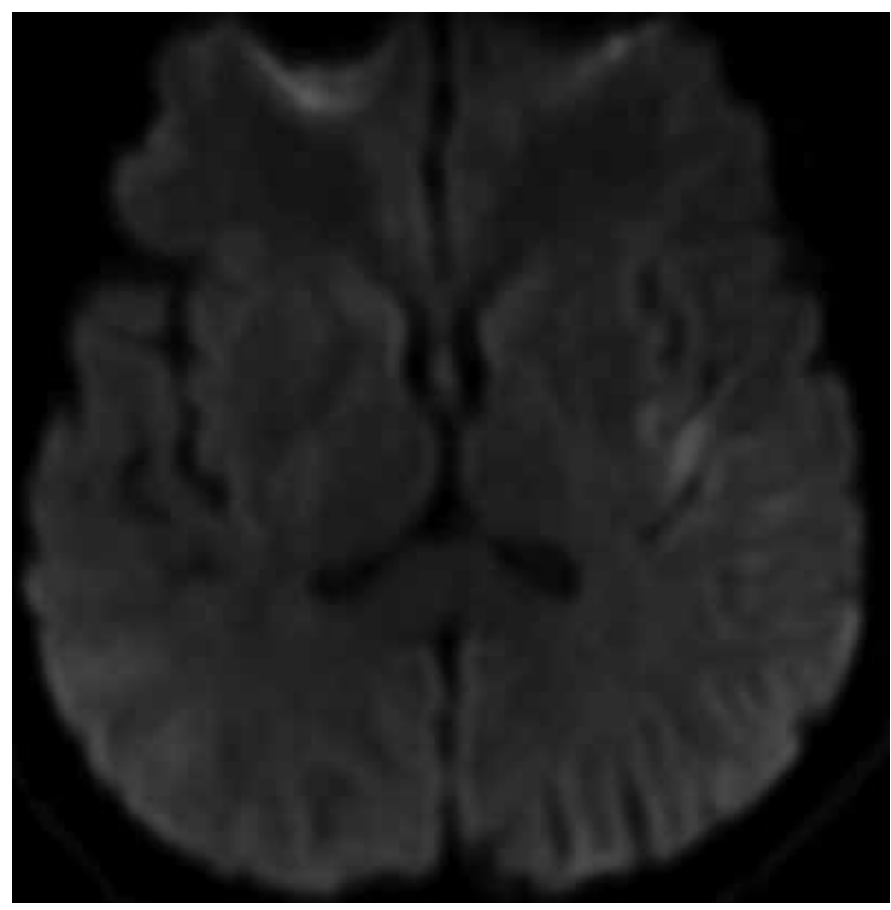

Figure 2a. Acute infarction in left middle cerebral artery territory in diffusion sequences of cranial magnetic resonance

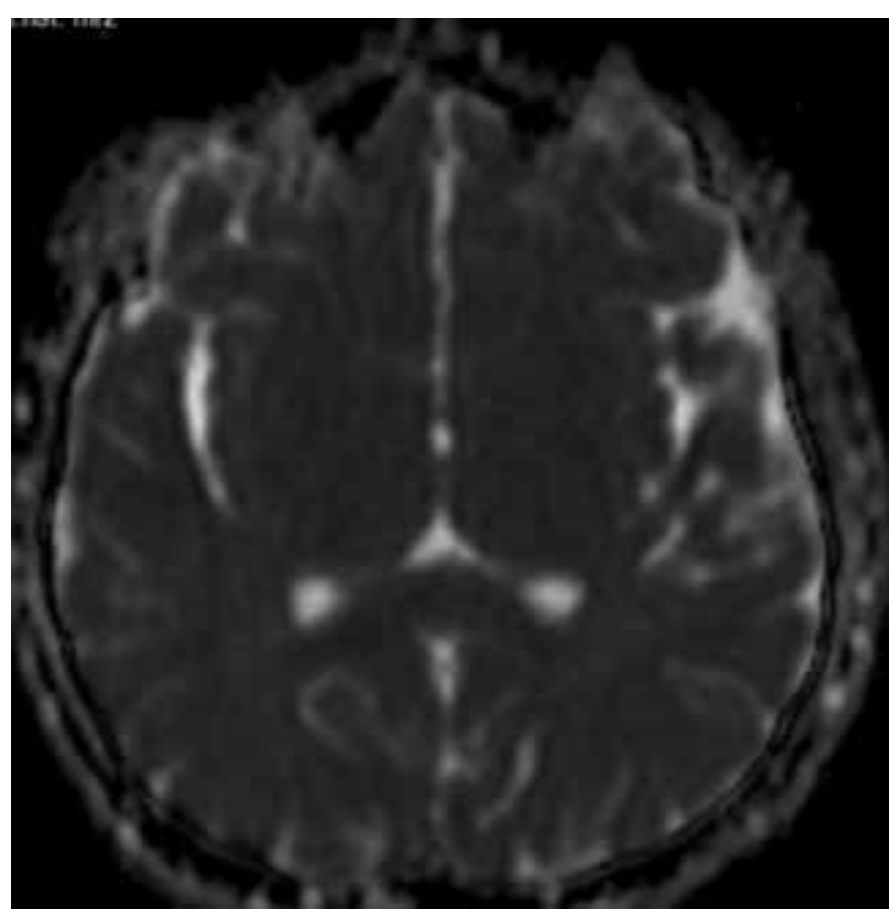

Figure 2b. Acute infarction in left middle cerebral artery territory in ADC sequences 
with cerebral infarction. Furthermore, of the 513 patients with Marfan's syndrome who made up the study group, the authors reported that mean age of the patients was younger than 40 years and overall atherosclerotic risk factors could be determined in few patients. Prosthetic heart disease, atrial fibrillation, mitral valve prolapses, and aortic root dilatation were more common cardiac pathologies in these patients. The relationship between Marfan's syndrome and atherosclerosis has been interpreted as follows: deficiency of fibrillin-1 disrupts the elastic lamina of aorta, which increases matrix metalloprotein activity involved in elastolysis, and leads to aortic dissection. Elevated homocysteine levels in Marfan's syndrome results in the accumulation of abnormal glycosaminoglycans in the extracellular matrix and disrupts the integrity of elastic lamina, which causes early atheroma plaque formation (7). Although atherosclerosis is thought to cause aortic dissection, the association between atheroma and localization of dissection has only been demonstrated in a small group of patients (8).

Our patient had prior history of surgery for aortic aneurysm and coronary by-pass, and unintervened dissection that extended from the abdominal aorta to the iliac artery. Observation of a pseudoaneurysm in segment $\mathrm{V} 2$ of the vertebral artery in cranial MR angiography suggested a clinically silent history of a vertebral artery dissection. No signs suggestive of large vessel atherosclerosis were determined in cranial MRA. All examinations

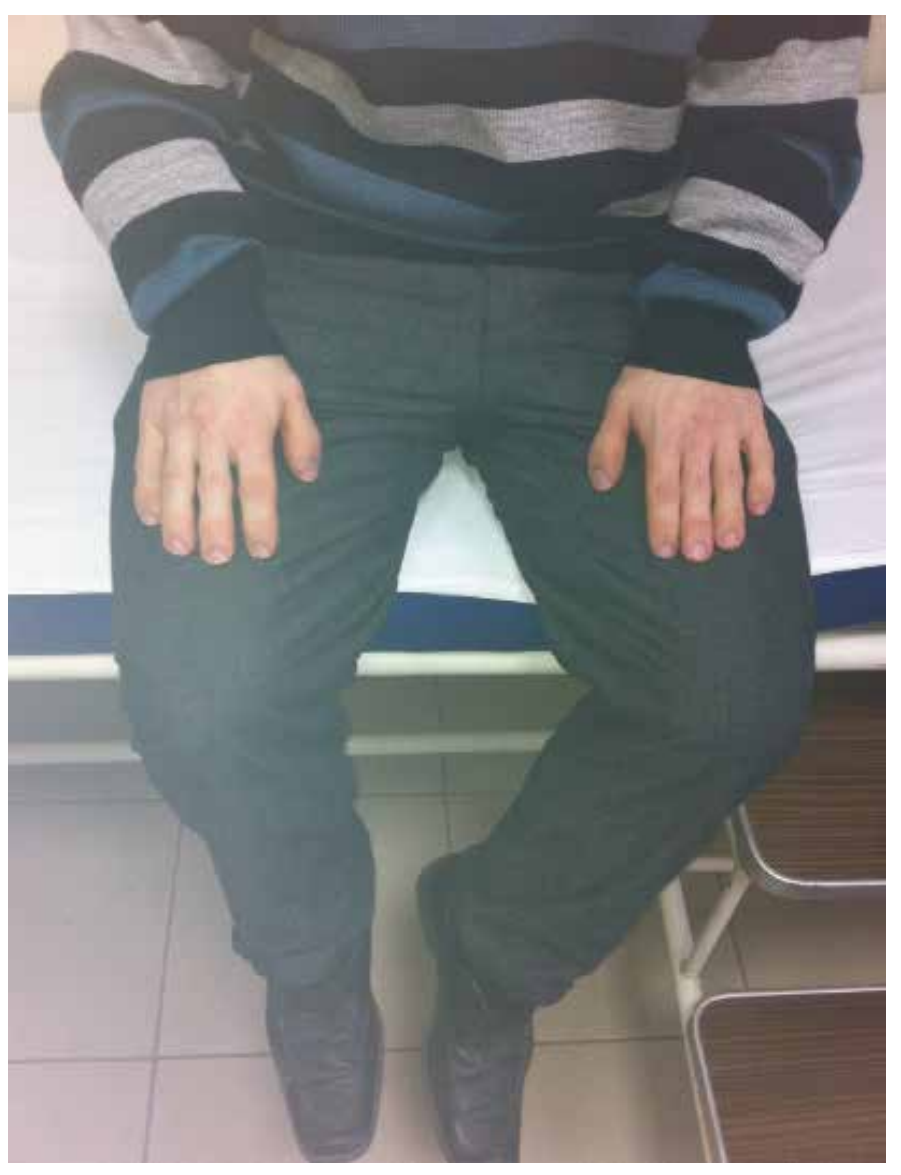

Figure 3a. Mesomelic shortening of extremities in Robinow syndrome of stroke etiology other than TEE were performed; nevertheless, no pathologies were determined. Mild hypertension was the only neurovascular risk factor. No abnormalities of cardiac origin were identified with the given examinations, but exclusion of TEE due to the risk posed by dissection was regarded as an important omission. The atherosclerotic risk factors of coronary artery disease and hypertension were considered to be secondary to the clinical picture of the patient. Gent criteria were used to establish a diagnosis (9); genotype analyses could not be performed due to financial issues (Table 1).

According to the Gent criteria, diagnosis of Marfan's syndrome requires the presence of major signs and/or one major plus 2 minor signs in at least two of the systems (10). Our patient was diagnosed as having Marfan's syndrome with the presence of major signs of skeletal and cardiovascular system involvement.

The rare genetic syndrome of Robinow is characterized by mesomelic shortening of extremities, fetal facies, and genital hypoplasia. Autosomal dominant and recessive forms are known to exist (11). The gene associated with the autosomal recessive form of Robinow syndrome is localized on the long arm of chromosome 9q22 and ROR2 tyrosine kinase is the enzyme responsible in the pathogenesis. There are no findings to support a major role of ROR2 tyrosine kinase in the dominant form $(11,12)$. Turkey is one of the countries in which the syndrome is comparatively

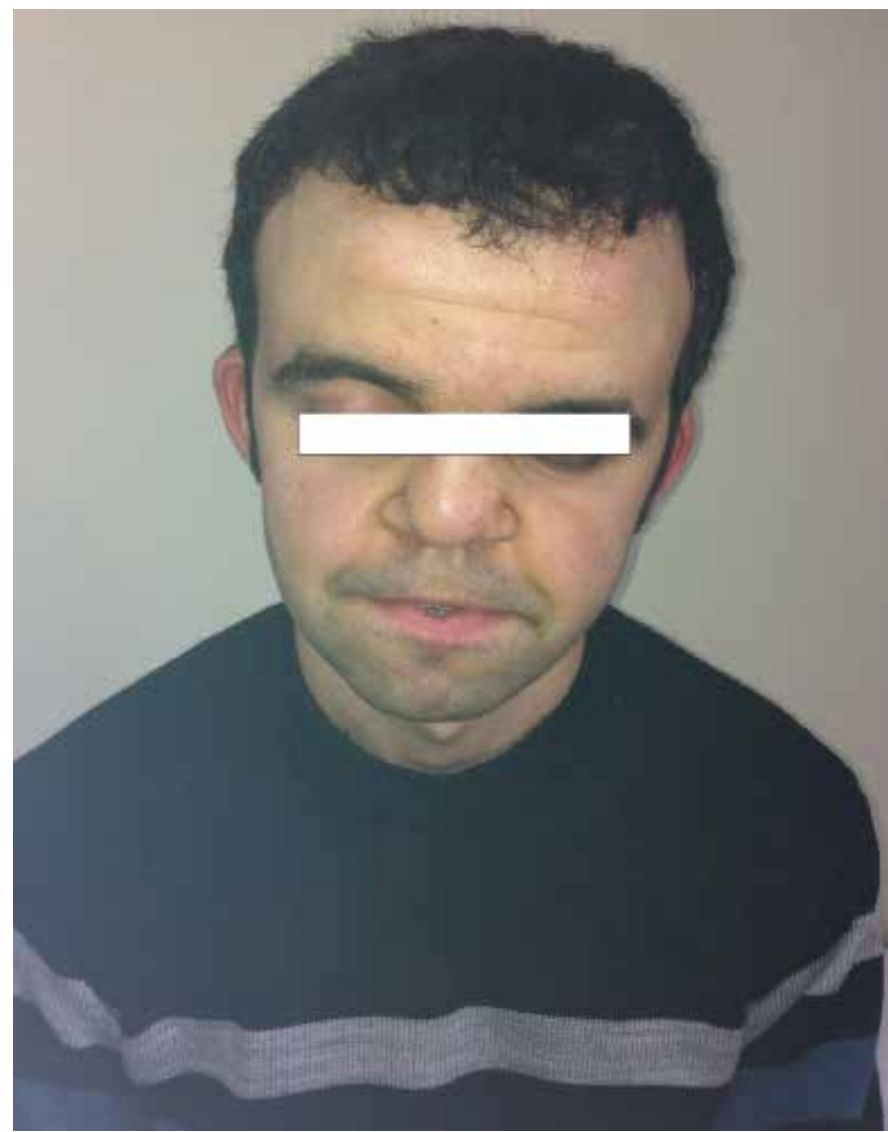

Figure 3b. Fetal facies, hypertelorism, upturned nose appearance in Robinow syndrome 
common. The recessive form has been reported to be particularly common in Turkey (12). Aksit et al. (13) identified that 20 of the 80 worldwide cases have been reported from Turkey, and the high rate of occurrence in Turkey rooted from the association of the disease with consanguinity in $21 \%$. Our patient had been diagnosed as

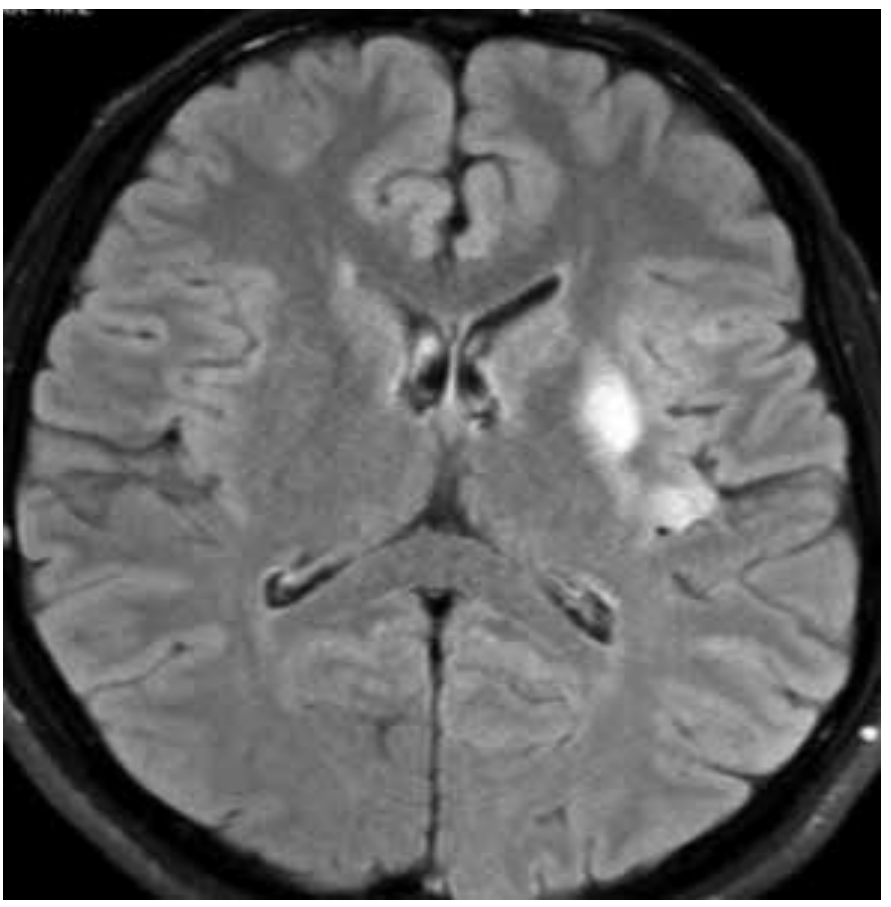

Figure 4a. Acute infarction in left middle cerebral artery territory

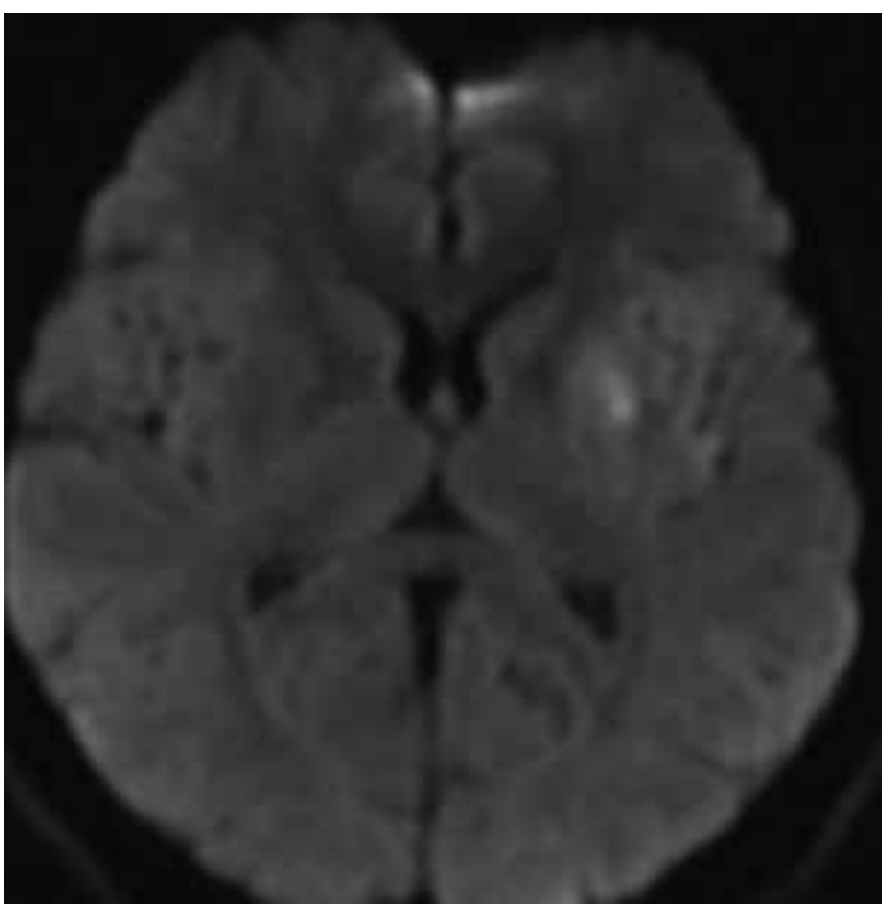

Figure 4b. Acute infarction in left middle cerebral artery territory in diffusion sequences having Robinow syndrome prior to the current presentation. He had a history of second degree consanguinity among parents, and his brother had also been diagnosed as having the same syndrome. The patient had no neurovascular risk factors, and no pathologies were determined in the etiologic search of stroke. There are no known reports in the literature that directly associates stroke with the Robinow syndrome. However, the study of Oguri et al. (14) on Japanese patients with chronic kidney failure and incident of stroke demonstrated that hypertension, diabetes, sex, age, and ROR2 genotype (recessive type) are associated with stroke. Additionally, Moyamoya disease has been determined in a child aged 13 years with Robinow syndrome who presented with repeated transient ischemic attacks (15). The literature on the relationship between Robinow syndrome and neurovascular disorders is restricted to these studies.

Consequently, genetic syndromes have entered the list of nonmodifiable risk factors in ischemic stroke. Among these, Marfan's syndrome is a connective tissue disorder that might cause ischemic stroke, particularly via dissection, and is more familiar due to its phenotypical features. Robinow syndrome is rather rare and requires further research and case studies to delineate its relationship with stroke. Our objective was to underline the importance of the search for genetic etiologies in stroke, particularly in the presence of significant phenotypical features. Identification of novel genetic syndromes should be included among stroke risk factors, and provision of genetic counseling might prevent neurovascular events in new generations.

Informed Consent: Patient consent was obtained for the photograph and manuscript. Concept: Eda Çoban, Nilüfer Kale

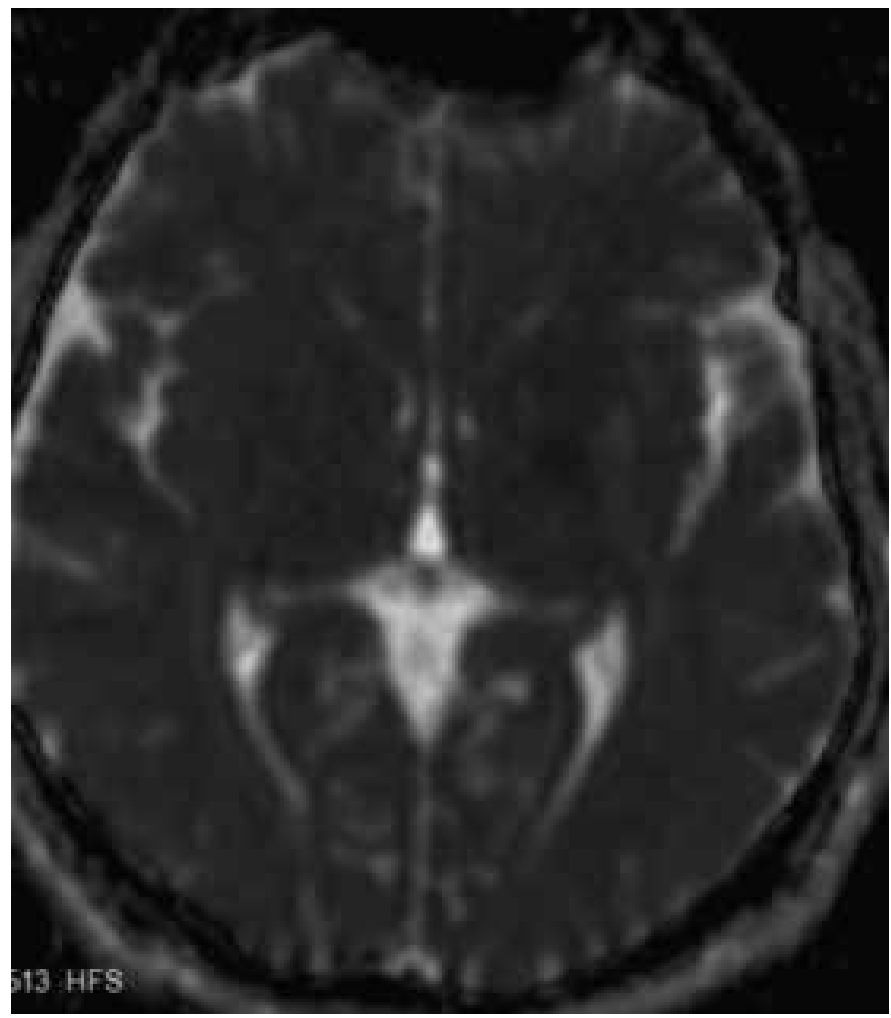

Figure 4c. Acute infarction in left middle cerebral artery territory in ADC sequences 


\begin{tabular}{|c|c|c|}
\hline & Major Criteria & Minor Criteria \\
\hline Skeletal system & $\begin{array}{l}\text { Pectus carinatum } \\
\text { Pectus excavatum (surgical) } \\
\text { Abnormal arm span/stature } \\
\text { Wrist and thumb sign } \\
\text { Increased scoliosis and spondylolistesis } \\
\text { Decreased elbow extension } \\
\text { Medial displacement of medial malleolus } \\
\text { Acetabular protrusion }\end{array}$ & $\begin{array}{l}\text { Pectus excavatum (moderate) } \\
\text { Hypermobile joints } \\
\text { High arched palate with crowding of teeth } \\
\text { Typical facial appearance }\end{array}$ \\
\hline Ocular system & & $\begin{array}{l}\text { Greater globe length } \\
\text { Hypoplasia of iris and ciliary muscle }\end{array}$ \\
\hline Cardio-vascular system & $\begin{array}{l}\text { Dilatation of ascending aorta } \pm \text { aortic } \\
\text { insufficiency } \\
\text { Involvement of Valsalva sinus } \\
\text { Type A dissection }\end{array}$ & $\begin{array}{l}\text { Mitral valve prolapsus } \pm \text { mitral insufficiency } \\
\text { Dilatation of pulmonary artery } \pm \text { pulmonary } \\
\text { stenosis } \\
\text { Calcified mitral annulus (age }<40 \text { years) } \\
\text { Aneurysm of abdominal or descending aorta / } \\
\text { dissection (age }<50 \text { years) }\end{array}$ \\
\hline Dura & Dural ectasia & \\
\hline Pulmonary system & & $\begin{array}{l}\text { Spontaneous pneumothorax } \\
\text { Apical blebs }\end{array}$ \\
\hline Skin & & $\begin{array}{l}\text { Striae (in the presence or absence of pregnancy) } \\
\text { Recurrent and incisional hernia }\end{array}$ \\
\hline Genetics & $\begin{array}{l}\text { Inheritence of fibrillin- } 1 \text { mutation DNA } \\
\text { haplotype is associated with familial Marfan's } \\
\text { syndrome }\end{array}$ & \\
\hline
\end{tabular}

İçen, Mesude Özerden, Melek Çolak Atmaca, Aysun Soysal, Design: Eda Çoban, Nilüfer Kale İçen, Mesude Özerden, Melek Çolak Atmaca, Aysun Soysal, Data Collection and Processing: Eda Çoban, Melek Çolak Atmaca, Analysis or Interpretation: Eda Çoban, Literature Search: Eda Çoban, Writer: Eda Çoban, Peer-review: External and internal peer-reviewed. Conflict of Interest: No conflict of interest was declared by the authors. Financial Disclosure: The authors declared that this study has received no financial support.

\section{References}

1. World Health Organisation. The WHO STEP wise approach to stroke surveillance. Geneva: WHO,2005.

2. Sacco RL, Ellenberg JH, Mohr JP, Tatemichi TK, Hier DB, Price TR, Wolf PA. I Infarcts of undetermined cause: the NINCDS Stroke Data Bank. Ann Neurol 1989;25:382-390.

3. Razvi SSM, Bone I. Single gene disorders causing ischaemic stroke. J Neurol 2006;253:685-700.

4. Dichgans M. Genetics of ischaemic stroke. Lancet Neurol 2007;6:149-161.

5. Schievink WI, Michels VV, Piepgras DG. Neurovascular manifestations of heritable connective tissue disorders: a review. Stroke 1994;25:889-903.

6. Wityk RJ, Zanferrari C, Oppenheimer S. Neurovascular complications of marfan syndrome: a retrospective, hospital-based study. Stroke 2002;33:680-684.
7. McCully KS. Homocysteine, marfan syndrome and arteriosclerosis. Eur Heart J 2003;24:1995-1996.

8. Macura KJ, Corl FM, Fishman EK, Bluemke DA. Pathogenesis in acute aortic syndromes: aortic dissection, intramural hematoma, and penetrating atherosclerotic aortic ulcer AJR Am J Roentgenol 2003;181:309-316.

9. Erentuğ V, Polat A, Kırali K, Akıncı E, Yakut C. Marfan sendromunda kardiyovasküler tutulum ve tedavi. Anadolu Kardiyol Derg 2005;5:46-52.

10. De Paepe A, Devereux RB, Dietz HC, Hennekam RC, Pyeritz RE. Revised diagnostic criteria for the Marfan syndrome. Am J Med Genet 1996;62:417426.

11. Patton MA, Afzal AR. Robinow syndrome. J Med Genet 2002;39:305-310.

12. van Bokhoven H, Celli J, Kayserili H, van Beusekom E, Balci S, Brussel W, Skovby F, Kerr B, Percin EF, Akarsu N,Brunner HG. Mutation of the gene encoding the ROR2 tyrosine kinase causes autosomal recessive Robinow syndrome. Nat Genet. 2000;25:423-426.

13. Akşit S, Aydinlioglu H, Dizdarer G, Caglayan S, Bektaşlar D, Cin A. Is the frequency of Robinow syndrome relatively high in Turkey? Four more case reports. Clin Genet 1997; 52:226-230.

14. Oguri M, Nagahiro T, Kamiya H, Ohno M, Kato K, Yokoi K, Yoshida T, Watanabe S, Metoki N, Yoshida H, Satoh K, Aoyagi Y, Nozowa Y, Yamada Y. Association of a polymorphism of ROR2 and ischemic stroke in Japanese individuals with chronic kidney disease. Experiment and Therapeutic Medicine 2010;1:377-384.

15. Qaiser R, Scott RM, Smith ER. Identification of an association between robinow syndrome and moyamoya. Pediatr Neurosurg 2009;45:69-72. 